Japanese Culture 



\title{
Japanese Culture
}

\section{THIRD EDITION}

\section{H. Paul Varley}

\author{
University of Hawait Press
}


(C) $1973,1977,1984$ by H. Paul Varley

All rights reserved

Manufactured in the United States of America

\section{THE EAST ASIAN INSTITUTE OF COLUMBIA UNIVERSITY}

The East Asian Institute was established in 1949 to prepare graduate students for careers dealing with East Asia, and to aid research and publication on East Asia during the modern period. The faculty of the Institute are grateful to the Ford Foundation and the Rockefeller Foundation for their financial assistance.

The Studies of the East Asian Institute were inaugurated in 1962 to bring to a wider public the results of significant new research on modern and contemporary East Asia.

\section{Library of Congress Cataloging in Publication Data}

Varley, H. Paul.

Japanese culture.

Bibliography: p.

Includes index.

1. Japan-Civilization. I. Title.

DS821.V36 $1984 \quad 952 \quad 84-2466$

ISBN 0-8248-0927-0 
To Donald Keene 